\title{
$\frac{100}{\text { LAT }}$ RPEiS
}

\section{KLAUZULA PRZECIWKO UNIKANIU OPODATKOWANIA: NORMA, DO KTÓREJ STOSOWANIA ZOBOWIĄZANY JEST PODATNIK, CZY REGULACJA STOSOWANA WYLĄCZNIE PRZEZ ORGAN PODATKOWY?}

\section{WPROWADZENIE}

Celem niniejszego artykułu jest omówienie problemu, czy do stosowania klauzuli przeciwko unikaniu opodatkowania ${ }^{1}$ zobowiązany jest sam podatnik, w procesie samodzielnego ustalania i deklarowania wymiaru podatku, czy też norma ta znajduje zastosowanie jedynie $\mathrm{w}$ toku specyficznych postępowań: postępowania podatkowego w przypadku unikania opodatkowania (art. 119g-119l O.p.) i cofnięcia skutków unikania opodatkowania (art. 119zfa $-119 z f n$ O.p.).

Wskazana problematyka nie doczekała się jak dotąd na gruncie znowelizowanych przepisów Ordynacji podatkowej kompleksowego opracowania. Rozstrzygnięcie wskazanego problemu ma tymczasem istotny wymiar praktyczny. Odpowiedź na pytanie, czy klauzulę ma obowiązek stosować sam podatnik, czy prawo to przysługuje wyłącznie organowi podatkowemu, determinuje w istotny sposób sytuację prawną jednostki. Jeżeli przyjmiemy, że podatnik przy obliczaniu i deklarowaniu podatku jest zobowiąany samodzielnie zastosować klauzulę, brak realizacji tego obowiązku będzie skutkować powstaniem zaległości podatkowej i obowiązkiem zapłaty odsetek za zwłokę od momentu jej powstania. Przy takim podejściu umyślne pominięcie zastosowania klauzuli może dodatkowo wiązać się dla podatnika z odpowiedzialnością karną skar-

* Mikołaj Kondej, kontakt@mikolajkondej.pl, https://orcid.org/0000-0002-9727-3931

** Jakub Pietrusiewicz, pietrusiewicz@gmail.com, https://orcid.org/0000-0001-8140-6966

1 Art. 119a i dalsze ustawy z 29 sierpnia 1997 r. - Ordynacja podatkowa (dalej jako: O.p.). 
bową ${ }^{2}$. Wynika to z faktu, że złożenie deklaracji bez uwzględnienia skutków tej normy może zostać potraktowane jako oszustwo podatkowe (art. 56 k.k.s.) ${ }^{3}$. Inaczej będzie w sytuacji, jeżeli przyjmiemy, że klauzulę może zastosować wyłącznie organ podatkowy. Wówczas podatnik, nie będąc zobowiązany do samodzielnego rozpoznania skutków zastosowania klauzuli w deklaracji, nie może też ponosić odpowiedzialności karnej skarbowej z tego tytułu ${ }^{4}$. Z drugiej strony brak możliwości samodzielnego zastosowania klauzuli przez podatnika może mieć dla niego również negatywne konsekwencje. Jeżeli bowiem zrealizuje on czynności stanowiące unikanie opodatkowania, a klauzuli nie będzie mógł zastosować samodzielnie, nie będzie mógł on tym samym odstapić od wykazania w deklaracji korzyści podatkowej spełniającej warunek sztuczności. Niemożliwe będzie tym samym uniknięcie przez niego ryzyka wymierzenia mu dodatkowego zobowiąania podatkowego ${ }^{5}$.

Rozstrzygnięcie, czy klauzula jest normą znajdująca zastosowanie z mocy prawa czy też wyłącznie w drodze decyzji Szefa Krajowej Administracji Skarbowej (Szef KAS), ma też istotne znaczenie dla ustalenia obowiązków płatnika podatku. Determinuje bowiem to, czy przy obliczaniu i poborze podatku płatnik ma obowiązek zweryfikować, czy okoliczności sprawy faktycznie wskazuja na unikanie opodatkowania. Będąca przedmiotem rozważań problematyka przekłada się również na to, czy płatnik ma prawo i obowiązek samodzielnie odmówić zastosowania zwolnienia podatkowego, przykładowo na podstawie art. $119 \S 6$ O.p., lub też pobrać podatek w kwocie właściwej dla czynności odpowiedniej. Przyjęcie tezy, iż zastosowanie klauzuli możliwe jest jedynie w drodze postępowań prowadzonych przez Szefa KAS, rodzi za to pytania o to, jak powinien zachować się płatnik, aby uniknąć ryzyka zastosowania wobec niego GAAR w przypadku podejrzenia unikania opodatkowania po stronie podatnika

Mając na uwadze praktyczny charakter zagadnienia, celem niniejszego artykułu jest próba odpowiedzi na pytanie, czy do stosowania klauzuli przeciwko unikaniu opodatkowania zobowiązany jest sam podatnik, czy też może jej zastosowanie stanowi dyskrecjonalne uprawnienie organu podatkowego. $\mathrm{Ze}$ względu na fakt, że zagadnieniu temu nie poświęca się w doktrynie większej uwagi, a znaczna część rozważań w publikacjach kończy się na przywołaniu uzasadnienia nowelizacji Ordynacji podatkowej, która weszła w życie 1 stycznia 2019 r., autorzy przy jego analizie posługują się w przeważającej mierze metodą dogmatycznoprawną.

${ }^{2}$ Kondej (2018a): 136.

${ }^{3}$ Poza zakresem rozważań autorzy pozostawiaja przy tym problem tego, czy klauzula przeciwko unikaniu opodatkowania jest normą dostatecznie precyzyjna, by mogła stanowić podstawę nałożenia podatku, a tym bardziej podstawę odpowiedzialności karnej skarbowej - wątpliwości w tym zakresie zgłaszano w doktrynie - zob. m.in. Bartosiewicz (2017): 33-34; Gomułowicz (2019): 14-20.

${ }^{4}$ Bartosiewicz (2017): 31-32.

${ }^{5}$ Art. 58a-58e O.p. 


\section{NOWELIZACJA PRZEPISÓW OBOWIĄZUJĄCYCH OD 1 STYCZNIA 2019 ROKU I JEJ UZASADNIENIE}

Ustawa nowelizująca przepisy Ordynacji podatkowej, która weszła w życie 1 stycznia 2019 r. ${ }^{6}$, wprowadziła formalna procedurę cofnięcia skutków unikania opodatkowania. Procedura ta ma, w świetle uzasadnienia projektu ustawy, umożliwić podatnikom wycofanie się ze skutków unikania opodatkowania. W uzasadnieniu wskazano, choć nie bez pewnego wahania, iż do stosowania klauzuli, od momentu jej wprowadzenia w 2016 r., nie był uprawniony sam podatnik. Klauzula miała znajdować zastosowanie jedynie w ramach postępowania $\mathrm{z}$ art. 119g O.p., w tym w trybie korekty dokonywanej w trakcie takiego postępowania. Po wydaniu decyzji w takim postępowaniu mogła być zastosowana również do podmiotu trzeciego, uczestniczącego w czynności uznanej za unikanie opodatkowania, ale samemu nieunikajacego opodatkowania, na zasadach wskazanych w art. 119j O.p.

Projektodawcy ustawy, uzasadniajac takie stanowisko, odwołali się między innymi do treści wyroku Wojewódzkiego Sądu Administracyjnego w Szczecinie z 31 maja 2017 r. (I SA/Sz 216/17), zgodnie z którym adresatem przepisów klauzuli jest Szef KAS, a sam podatnik nie ma możliwości ich zastosowania ${ }^{7}$. Podnieśli oni, że choć podatnicy mają teoretyczne prawo do złożenia deklaracji lub korekty deklaracji z uwzględnieniem takiego stanu rzeczy, jak gdyby podatnik nie unikał opodatkowania, jednak takie działanie „może zostać uznane za niewłaściwe i ze względów systemowych nie powinno zyskać aprobaty organów podatkowych”. W uzasadnieniu projektu stwierdzono, że deklaracja lub jej korekta składane przez podatnika powinna odzwierciedlać podatkowe skutki rzeczywiście zaistniałych zdarzeń, a nie stanu faktycznego, który stanowi podstawę ustalenia wymiaru podatku na podstawie przepisów klauzuli.

Teza o tym, iż klauzuli przeciwko unikaniu opodatkowania, w stanie prawnym obowiąującym do 31 grudnia 2018 r., nie mógł zastosować sam podatnik, jest jednak kontrowersyjna. Nie jest ona też, mimo wspomnianej wcześniej nowelizacji przepisów, oczywista w stanie prawnym obowiązującym od 1 stycznia 2019 r. $^{8}$

${ }^{6}$ Ustawa z 23 października 2018 r. o zmianie ustawy - Ordynacja podatkowa oraz niektórych innych ustaw (dalej jako: ustawa zmieniająca).

${ }^{7}$ Jak wskazał WSA w Szczecinie w uzasadnieniu wskazanego orzeczenia „adresatem art. 119a-119f O.p. jest organ wymieniony w art. 119g § 1 O.p., tym samym nie sposób przyjać, by skarżąca miała się zastosować do interpretacji indywidualnej rozstrzygającej o kompetencjach danego organu, a nie o skutkach podatkowych dla samego podatnika”.

${ }^{8}$ Za obowiązkiem stosowania klauzuli z mocy prawa, a więc przez samego podatnika, opowiedzieli się m.in.: Guzek, Stefaniak (2018): 91; Kujawski (2017): 121; Kondej (2018a): 19-22; Kondej (2019): 5-14. Odmiennie m.in.: Liszewski (2021): Komentarz do art. 119zfa O.p.; Porada (2021): 600; Łukawska-Białogłowska (2020): Komentarz do art. 119zfa O.p.; Olesiak, Pajor (2020): pkt IX podpkt 2; Filipczyk (2016): 12. 


\section{LITERA PRAWA}

O tym, iż intencja pierwotnych projektodawców klauzuli było, aby jej przepisy stosowało się z mocy prawa, wydaje się świadczyć już sam sposób sformułowania regulacji. Posłużenie się w ich treści formą bezosobową czasowników: nie skutkuje czy określa się zdaje się wskazywać na automatyzm działania normy (jej działanie ex lege).

Istotnym argumentem wskazującym na stosowanie klauzuli z mocy prawa jest też fakt, iż zgodnie z zarówno historycznym, jak i obecnym brzmieniem art. 119g $§ 1$ O.p. Szef KAS wszczyna postępowanie podatkowe lub przejmuje do dalszego prowadzenia postępowanie podatkowe, kontrolę podatkowa lub kontrolę celno-skarbową m.in. w przypadkach, w których na podstawie art. 119a O.p. może zostać wydana decyzja w sprawie określenia lub ustalenia wysokości zobowiązania podatkowego, a także określenia straty podatkowej. Decyzje określające maja charakter deklaratoryjny, dotyczą zatem zobowiazań powstających z mocy prawa. Skoro ustawodawca, w wyniku postępowania z art. 119a O.p., dopuszcza wydanie decyzji określającej wysokość zobowiązania podatkowego, oznacza to, że przyjmuje, iż zastosowanie klauzuli prowadzi do ustalenia właściwej wysokości pierwotnie powstałego zobowiązania podatkowego. Decyzja wymiarowa na podstawie klauzuli wywiera więc skutki nie od momentu wydania decyzji o jej zastosowaniu (ex nunc), a wstecz, od momentu, gdy powstało zobowiązanie podatkowe (ex tunc). Odwołanie się przez ustawodawcę w treści art. 119g § 1 O.p. do terminu „decyzja określająca” wydaje się więc wskazywać, iż zakłada on, że już w momencie dokonania czynności przez podatnika ustalenie prawidłowej kwoty zobowiąania podatkowego wymaga zastosowania klauzuli, ergo że znajduje ona zastosowanie z mocy prawa.

Odmienny pogląd w tym zakresie prezentuje Hanna Filipczyk, która wskazuje, iż decyzja na podstawie klauzuli, w odniesieniu do podatków, w których zobowiąanie podatkowe powstaje $\mathrm{z}$ mocy prawa, ma dychotomiczny charakter. Zdaniem Filipczyk decyzja taka ma z jednej strony kreować skutki podatkowe (w tym zakresie ma ona mieć więc charakter konstytutywny), z drugiej zaś - odnosząc się do przeszłości, skutkować korektą rozliczenia podatnika (w tym zakresie ma więc ona mieć charakter deklaratoryjny). Według wskazanej autorki taki dychotomiczny charakter decyzji ma oznaczać m.in. obowiązek zapłaty odsetek za zwłokę za okres od dnia następującego po dniu, w którym podatnik powinien był dokonać zapłaty podatku od czynności „odpowiedniej”.

W ocenie autorów pogląd Filipczyk o dychotomicznym charakterze decyzji wymiarowej na podstawie klauzuli, choć ciekawy, ma szereg istotnych mankamentów. Po pierwsze, dla takiego poglądu trudno znaleźć podstawę normatywna. Ustawodawca w treści przepisów odwołuje się do dotychczas używanych pojęć (decyzji określającej/ustalającej), nie wskazując wprost, iż należy nadawać im nowe znaczenie. Powstaje więc pytanie o to, skąd czerpać uzasadnienie takiego sposobu interpretacji. Dualizm poglądów rozróżniających zobowiązania

${ }^{9}$ Filipczyk (2016): 15. 
powstające z mocy prawa i na mocy decyzji wydaje się utrwalony ${ }^{10}$, a przepisy o klauzuli nie wydaja się dawać dostatecznych podstaw do jego podważenia. Po drugie, funkcjonowanie w obrocie decyzji konstytutywno-deklaratywnych przeczyłoby przyjętej istocie samodzielnego wymiaru podatku przez podatnika. W tych podatkach, gdzie zobowiązanie podatkowe powstaje z mocy prawa, przyjęło się, iż podatnik winien ustalić poprawną kwotę podatku do zapłaty, a następnie ją regulować. Bez wyraźnej podstawy normatywnej trudno przyjać, iż podatnik miałby przy dokonywaniu takiego ustalenia pominąć część obowiąujących przepisów, tzn. klauzulę przeciwko unikaniu opodatkowania. Wątpliwa jest także zasadność podejścia, w którym w przypadku zastosowania klauzuli zobowiązania podatkowe powstają ze skutkiem wstecznym. Wykładnia taka prowadzi choćby do wypaczenia istoty odsetek za zwłokę. Fakt, że zobowiązanie podatkowe powstaje w momencie wydania decyzji, ale ze skutkiem wstecznym, prowadzi do tego, że odsetki takie stają się należne za okres, gdy zobowiązanie jeszcze nie istniało. Rolą odsetek jest tymczasem rekompensowanie Skarbowi Państwa opóźnienia w płatności ${ }^{11}$, które w takim przypadku w ogóle nie występuje (zaległość podatkowa powstaje dopiero na skutek decyzji).

Warto też zwrócić uwagę, iż w toku postępowania na podstawie art. 119a O.p., jak i na skutek decyzji o cofnięciu skutków unikania opodatkowania, ustawodawca wprost przyznaje podatnikowi prawo do samodzielnej korekty deklaracji ${ }^{12}$. Oznacza to, że nie można przyjąć, iż do zastosowania klauzuli potrzebna jest konstytutywno-deklaratywna decyzja organu. Ustawodawca explicite wskazuje bowiem, że klauzulę może w takim przypadku zastosować sam podatnik. W tym kontekście należy wskazać, iż żaden przepis klauzuli nie zawęża prawa do złożenia przez podatnika korekty uwzględniającej skutki zastosowania klauzuli wyłącznie do wskazanych postępowań. Wręcz przeciwnie, art. 81b $\S 1$ O.p. interpretowany a contrario wskazuje, iz taka korekta jest dopuszczalna zawsze.

Na możliwość zastosowania klauzuli przez podatnika wskazuje również uzasadnienie ustawy, na mocy której klauzula weszła w życie. Wynika z niego m.in., że czynność stanowiąca unikanie opodatkowania jest automatycznie nieskuteczna na gruncie prawa podatkowego, a jej skutki podatkowe sa ustalane z pominięciem sztucznych czynności. Obrazuje to poniższy cytat.

Jeśli podatnik dokona sztucznej czynności, aby osiagnąć korzystny rezultat podatkowy, stojący w sprzeczności z istotą regulacji podatkowej, to skuteczność tego rodzaju działania zostanie prawnie zniweczona (art. 119a $\S 1$ ). Warunkiem pozbawienia takiej czynności jej skuteczności w sferze prawa podatkowego będzie spełnienie łącznie przesłanki sztuczności i działania przede wszystkim w celu osiagnięcia korzyści podatkowej, jeśli taka korzyść w danych okolicznościach byłaby sprzeczna z przedmiotem i celem przepisu ustawy podatkowej. Taką czynność us taw a uznawać będzie za unikanie opodatkowania i będzie mu przeciwdziałać [wyróżnienia autorów].

${ }^{10}$ Niezgódka-Medek (2019): Komentarz do art. 5 O.p.; Dzwonkowski, Dzwonkowski (2020): Komentarz do art. 5 O.p.

11 Zgodnie z art. $51 \S 1$ O.p. zaległością podatkowa jest podatek niezapłacony w terminie płatności. Jednocześnie zgodnie z art. 53 § 1 od zaległości podatkowych naliczane są odsetki za zwłokę. Por. również wyrok WSA w Bydgoszczy z 6 listopada 2018 r., I SA/Bd 580/18.

12 Art. $81 \mathrm{~b} \S 1 \mathrm{a}$ O.p. 
Równocześnie w uzasadnieniu ustawy, na mocy której klauzula weszła w życie, brak jakichkolwiek wskazówek, by norma ta miała być stosowana jedynie w drodze decyzji organu.

Projektodawca ustawy zmieniającej sugeruje, iż o tym, że zastosowanie klauzuli od początku było możliwe jedynie w toku postępowania w sprawie unikania opodatkowania, świadczy interpretacja a contrario art. $119 \mathrm{j} \S 1$, zgodnie z którym:

\footnotetext{
Podmiot inny niż strona postępowania zakończonego decyzją wydaną w sprawie, o której mowa w art. $119 \mathrm{~g} \S 1$, uczestniczący w czynności, której skutki podatkowe określono w tej decyzji, z wyłączeniem skutków podatkowych określonych na podstawie art. 119a § 6, może skorygować swoja deklarację, uwzględniając treść decyzji, a także wystapić z wnioskiem o stwierdzenie nadpłaty lub zwrot podatku, jeżeli decyzja jest ostateczna, a w przypadku złożenia skargi - jeżeli sąd administracyjny prawomocnie oddalił skargę na tę decyzję, oraz decyzja ta została wykonana w całości.
}

Zdaniem projektodawcy przepis ten powinien być odczytywany jako wyjatek od reguły, iż klauzula może znaleźć zastosowanie jedynie w toku postępowania w sprawie unikania opodatkowania. Wskazuje on, że gdyby klauzulę mógł stosować sam podatnik, to wskazana regulacja nie byłaby potrzebna.

Nie jest to, naszym zdaniem, argument trafny. Artykuł 119j § 1 O.p. nie jest bowiem skierowany do podmiotu, do którego zastosowanie może znaleźć klauzula przeciwko unikaniu opodatkowania. Dotyczy on osoby trzeciej, która co prawda uczestniczy w określonej transakcji, ale samemu nie unika opodatkowania. W odniesieniu do takiego podmiotu hipoteza klauzuli nie będzie spełniona, a więc nie znajdzie zastosowania również jej dyspozycja. Artykuł 119j $§ 1$ O.p. został wprowadzony po to, by osoba trzecia mogła w takiej sytuacji mimo to skorygować swoje rozliczenia. Ratio legis wskazanej regulacji leży w dążeniu do wyeliminowania asymetrii opodatkowania. Mogłaby ona wystapić w sytuacji, w której skutki podatkowe po stronie podmiotu unikającego opodatkowania zostałyby określone nie na podstawie faktycznie dokonanych przez podatnika czynności, a na podstawie reguł przewidzianych w dyspozycji klauzuli, a po stronie jego kontrahenta opodatkowaniu podlegałaby czynność faktycznie dokonana.

Karol Kwiatkowski, dyskutując z tezą o stosowaniu klauzuli z mocy prawa, podniósł wątpliwość związaną z brzmieniem art. 119d O.p. Zgodnie z tym przepisem „przy ocenie, czy osiagnięcie korzyści podatkowej było głównym lub jednym z głównych celów dokonania czynności, bierze się pod uwagę cele ekonomiczne czynności wskazane przez stronę". Wskazał on, że w przypadku samodzielnego zastosowania klauzuli podatnik nie miałby komu celów wskazywać. Autorzy niniejszego tekstu art. 119d O.p. odczytuja jednak nie jako przepis przesądzający o tym, że tylko organ może stosować klauzulę, ale jako swego rodzaju gwarancję proceduralną na wypadek weryfikacji rozliczeń podatnika ze strony organów podatkowych. Nakazuje ona organom podatkowym, gdy rozważana jest możliwość zastosowania klauzuli, uwzględnić wszystkie cele, które realnie mogły podatnikowi przyświecać przy dokonaniu czynności. 
Należy zwrócić uwagę, iż klauzula przeciwko unikaniu opodatkowania jest wzorowana na standardach europejskich. W tym kontekście warto przywołać brzmienie dyrektywy ATA $^{13}$, która przewiduje obowiązek implementacji przez Polskę ogólnej klauzuli antyabuzywnej. Z dyrektywy tej wynika wprost, że państwo członkowskie jest zobowiązane (a nie upoważnione) do pominięcia czynności sprzecznych z celem lub przepisem ustawy podatkowej, podjętych w celu osiagnięcia korzyści podatkowej. Nie wydaje się, aby dyrektywa ATA dopuszczała uznaniowość w tym zakresie.

Kontrargumentację odnoszącą się do wątku europejskiego przedstawił Kwiatkowski ${ }^{14}$. Nawiązał on m.in. do punktów 4.2, 4.4 oraz 4.7 zaleceń Komisji Europejskiej ${ }^{15}$. Pierwszy $\mathrm{z}$ wymienionych punktów zawiera proponowaną treść klauzuli: „Nie uwzględnia się sztucznego uzgodnienia lub szeregu sztucznych uzgodnień [...] Krajowe organy rozpatruja te ustalenia [...]". Zgodnie z interpretacją Kwiatkowskiego zapis ten ma świadczyć o intencji, by klauzulę stosowały wyłącznie organy ${ }^{16}$. Warto zwrócić jednak uwagę, iż zapis ten w toku dalszych prac organów Unii Europejskiej uległ modyfikacjom. Bez zmian pozostała forma czasownikowa „nie uwzględnia się”, ale fragment „krajowe organy rozpatrują te ustalenia" ewoluował w art. 6 ust. 3 dyrektywy ATA do zgoła innej formy: „zobowiązanie podatkowe oblicza się zgodnie z prawem krajowym".

\section{STOSOWANIE KLAUZULI PRZEZ PODATNIKA A MOŻLIWOŚĆ WERYFIKACJI PRAWIDŁOWOŚCI ROZLICZENIA}

W uzasadnieniu ustawy zmieniającej podniesiono argument, iż przyjęcie tezy o możliwości zastosowania klauzuli z mocy prawa prowadziłoby do sytuacji, w której podatnik sam mógłby opodatkować się na podstawie czynności odpowiedniej, a organ podatkowy, inny niż Szef KAS, zobligowany byłby do weryfikowania prawidłowości takiej deklaracji podatkowej. Zdaniem projektodawcy ustawy byłoby to nielogiczne. Trudno zgodzić się z taką oceną. Zgodnie bowiem z art. 119g $§ 1$ O.p., jeżeli w danej sprawie może zostać wydana decyzja z zastosowaniem klauzuli, Szef KAS przejmuje kontrolę podatkowa, kontrolę celno-skarbowa, a także przejmuje lub wszczyna postępowanie podatkowe. W konsekwencji nawet gdyby podatnik w deklaracji samemu opodatkował się na podstawie klauzuli, to organy, badając prawidłowość deklaracji, mogłyby stwierdzić, iż nie znajduje ona w ogóle zastosowania, i wymierzyć podatek

13 Mowa o dyrektywie Rady (UE) 2016/1164 z12 lipca 2016 r. ustanawiającej przepisy mające na celu przeciwdziałanie praktykom unikania opodatkowania, które mają bezpośredni wpływ na funkcjonowanie rynku wewnętrznego.

14 <https://119a.kwiatkowski.pro/2019/02/klauzula-generalna-uprawnienie-tylko.html>

15 Mowa o zaleceniach Komisji Europejskiej z 6 grudnia 2012 r. w sprawie agresywnego planowania podatkowego.

16 <https://119a.kwiatkowski.pro/2019/02/klauzula-generalna-uprawnienie-tylko.html> 
z pominięciem jej przepisów bądź też, w razie stwierdzenia, iż klauzula może znaleźć zastosowanie, przekazać sprawę Szefowi KAS ${ }^{17}$.

Nietrafne wydaje się też założenie autorów projektu ustawy nowelizującej, iż zastosowanie klauzuli przez podatnika prowadziłoby do wykazania w deklaracji kwot „nieodpowiadających rzeczywistym zdarzeniom”. Przepisy klauzuli maja charakter materialnoprawny i stanowia w istocie nowy wzorzec subsumpcji określonych stanów faktycznych. Z tej przyczyny stosowanie klauzuli nie prowadzi do zadeklarowania zobowiąania podatkowego w wysokości „nieodpowiadającej rzeczywistym zdarzeniom”, lecz do określenia alternatywnych, względem standardowo stosowanych przepisów podatkowych, zasad opodatkowania zdarzeń zakwalifikowanych jako unikanie opodatkowania ${ }^{18}$.

Inna kwestia pozostaje zdaniem autorów fakt, że organy skarbowe powinny dysponować wiedzą o tym, iż podatnik zastosował samodzielnie klauzulę przeciwko unikaniu opodatkowania. De lege ferenda potrzebny jest więc odpowiednio skonstruowany wymóg raportowania takich przypadków, który umożliwi Szefowi KAS analizę prawidłowości działań podatników oraz podjęcie działań kontrolnych, tam gdzie sposób samodzielnego zastosowania klauzuli przez podatnika będzie nastręczał wątpliwości.

\section{ZASADY POWSZECHNOŚCI I RÓWNOŚCI OPODATKOWANIA A UZNANIOWOŚĆ DECYZJI ORGANU}

Zdaniem autorów zasada równości i powszechności opodatkowania może podawać w wątpliwość taką interpretację przepisów, zgodnie z którą sposób opodatkowania danej czynności przez różne podmioty nie będzie zależał od obiektywnych zasad, lecz od podjęcia lub niepodjęcia przez organ decyzji o wszczęciu wobec danego podatnika postępowania z art. 119a O.p. Jak wskazuje się w orzecznictwie Trybunału Konstytucyjnego, zawarta w art. 84 Konstytucji zasada powszechności opodatkowania stanowi odzwierciedlenie zasady równości ${ }^{19}$. Jej istotą pozostaje, aby podmioty znajdujące się w analogicznej sytuacji były obciążone podatkiem w równym stopniu ${ }^{20}$. Powyższe znajduje potwierdzenie m.in. w wyroku TK z 18 października 2011 r. $^{21}$,

17 Pewne wątpliwości w tym zakresie mogą powstać na gruncie czynności sprawdzających. Jednym z celów takich czynności, zgodnie z art. 272 pkt 3 O.p., jest ustalenie stanu faktycznego w zakresie niezbędnym do stwierdzenia zgodności rozliczenia z przedstawionymi dokumentami. Czynności takie prowadzą organy podatkowe inne niż Szef KAS, który jest uprawniony do zastosowania klauzuli. W sytuacji, w której podatnik samodzielnie zastosowałby klauzulę i przykładowo opodatkował czynność odpowiednia, mogłoby dojść do rozbieżności pomiędzy treścią dokumentacji a rozpoznanym wynikiem podatkowym na transakcji. W takim przypadku organy podatkowe mogłyby objąć dany stan faktyczny kontrolą podatkowa, przekazując ją następnie do Szefa KAS.

18 Podobnie m.in.: Jankowski (2020): 25-26, Ladziński (2019): 26.

19 Wyrok TK z 20 listopada 2002 r., K 41/02.

${ }^{20}$ Działocha, Łukaszczuk (2016): 979-985.

21 Wyrok TK z 18 października 2011 r., SK 2/10. 
w którym wskazano, że „z zasady równości podatkowej wynika, że wszystkie podmioty, będące w takiej samej sytuacji ekonomicznej (w zakresie stanu majątkowego, rodzajów źródeł przychodów i ich wielkości), powinny być opodatkowane równo".

Uzależnienie sposobu opodatkowania od dyskrecjonalnej decyzji organu podatkowego (w zakresie wszczęcia w określonej sprawie postępowania zmierzającego do zastosowania przepisów klauzuli), z czym mielibyśmy do czynienia, przyjmując, że zastosowanie dyspozycji klauzuli nie następuje automatycznie $^{22}$, stanowi zagrożenie dla realizacji tej zasady ${ }^{23}$. Przy takim podejściu możliwa staje się bowiem sytuacja, w której w stosunku do dwóch podmiotów znajdujących się w analogicznym stanie faktycznym znajdą zastosowanie różne zasady opodatkowania. W takim przypadku wymiar zobowiąania podatkowego, które dany podmiot jest zobowiązany uregulować, przestaje jednoznacznie wynikać z przepisów, a zaczyna być uzależniony od dyskrecjonalnej decyzji organu podatkowego. Dwóch podatników znajdujacych się w identycznym stanie faktycznym może być zobowiązanych do zapłaty podatku w różnej kwocie, w zależności od tego, czy Szef KAS zainicjuje wobec nich postępowanie na podstawie art. 119a O.p. czy też nie. Sytuacja taka nie dość, że może naruszać zasadę równości i sprawiedliwości, to dodatkowo wydaje się rodzić ryzyko nadużyć. Zrealizowałoby się ono, gdyby organ przez wybiórcze stosowanie normy antyabuzywnej dążył do zwiększenia obciążeń podatkowych jednych podmiotów względem innych.

W kontekście zarzutu potencjalnego nierównego traktowania Kwiatkowski podniósł kontrargument ${ }^{24}$, iż obecnie obowiąująca klauzula nie jest pierwszą regulacją w tym zakresie. Pierwotna klauzula została uchylona w $2004 \mathrm{r}$. przez TK ${ }^{25}$. Przepis był literalnie adresowany do organów państwowych, lecz TK nie wskazał tej cechy jako wady ${ }^{26}$. W ocenie autorów powyższe w żadnej mierze nie przesądza o tym, jak powinna być interpretowana obecnie obowiąująca klauzula, szczególnie że powyższa kwestia nie była w przedmiotem szczegółowych refleksji TK w 2004 r. Podkreślenia wymaga przy tym, że we wskazanym orzeczeniu Trybunał wyraźnie opowiadał się przeciwko dopuszczeniu uznaniowości przy stosowaniu klauzuli antyabuzywnej, choć jego refleksje w tym zakresie odnosiły się do tego, iż uznaniowość wynikała w omawianym przypadku z braku precyzyjnego sformułowania warunków zastosowania klauzuli ${ }^{27}$.

22 Automatycznie z mocy prawa, tzn. w taki sposób, iż podatnik jest zobowiązany do samodzielnego uwzględnienia skutków zastosowania klauzuli w przypadku spełnienia kryteriów jej zastosowania.

${ }^{23} \mathrm{Na}$ to, że klauzula przeciwko unikaniu opodatkowania nie powinna umożliwiać arbitralnego ustalania kwoty należnego zobowiązania podatkowego, zwraca uwagę m.in. Kuźniacki (2020): 21.

24 <https://119a.kwiatkowski.pro/2019/02/klauzula-generalna-uprawnienie-tylko.html>

25 W tym zakresie zobacz Olesińska (2013).

${ }_{26}$ Mowa o art. 24b § 1 O.p. w brzmieniu obowiązującym do 31 maja 2004 r.

27 Wyrok TK z 11 maja 2014 r., K 4/03. 


\section{ZMIANY WPROWADZONE USTAWĄ ZMIENIAJĄCĄ, OBOWIĄZUJĄCE OD 1 STYCZNIA 2019 ROKU}

Jak już wspomniano, projektodawcy ustawy zmieniającej, która wprowadziła istotne zmiany w klauzuli obowiąujące od 1 stycznia 2019 r., przyjęli założenie, że klauzula przeciwko unikaniu opodatkowania znajdowała, od momentu jej wprowadzenia do porządku prawnego, zastosowanie z mocy prawa. W efekcie przyjęcia takiego założenia nie dokonano takich modyfikacji przepisów, które wskazywałyby jasno, że do stosowania klauzuli uprawniony jest wyłącznie organ podatkowy. Co więcej, niektóre z dokonanych zmian wydaja się przeczyć zasadności tej tezy.

Ustawa zmieniajaca wprowadziła, opisana w rozdz. 5. O.p., procedure cofnięcia skutków unikania opodatkowania. Zakłada ona, że Szef KAS, na wniosek zainteresowanego, może wydać decyzję określającą warunki cofnięcia skutków unikania opodatkowania. W postępowaniu o wydanie takiej decyzji przyjmuje się założenie, że wskazana we wniosku czynność spełnia przesłanki uznania jej za unikanie opodatkowania.

W przypadku wydania przez Szefa KAS takiej decyzji zainteresowany może, w terminie 14 dni od dnia jej otrzymania, cofnać skutki unikania opodatkowania przez skorygowanie swoich rozliczeń podatkowych z uwzględnieniem treści decyzji. W takim przypadku organy podatkowe sa zobowiązane uwzględnić w toku kontroli podatkowej, kontroli celno-skarbowej lub postępowania podatkowego dokonana przez podatnika korektę. Uzyskanie decyzji określającej warunki cofnięcia skutków unikania opodatkowania i odpowiednie skorygowanie rozliczeń podatkowych daje zatem podatnikowi pewność prawidłowego zastosowania klauzuli.

Wprowadzona regulacja w żaden sposób nie wskazuje na niedopuszczalność dokonania przez podatnika korekty na zasadach ogólnych. W ocenie autorów procedura cofnięcia skutków unikania opodatkowania działa na podobnych zasadach jak postępowanie o wydanie indywidualnej interpretacji podatkowej. Mianowicie, Szef KAS wskazuje w stosownej decyzji prawidłowy sposób zastosowania przepisów klauzuli w konkretnym stanie faktycznym, dając zainteresowanym gwarancję skutecznego wycofania się ze skutków unikania opodatkowania w przypadku dokonania korekty zgodnej z treścią decyzji. Nie jest to jednak procedura skutkująca automatycznym skorygowaniem rozliczeń.

W stanie prawnym obowiąującym od 1 stycznia 2019 r. rozszerzony został też zakres sytuacji, w których można wydać decyzję z zastosowaniem klauzuli, m.in. o odpowiedzialność płatników lub inkasentów za podatek niepobrany lub pobrany, a niewpłacony oraz odpowiedzialność podatnika za podatek niepobrany przez płatnika ${ }^{28}$. Zgodnie z uzasadnieniem ustawy zmieniającej celem wskazanej zmiany było przeciwdziałanie unikaniu opodatkowania dochodu u źródła. Na gruncie przepisów klauzuli przed nowelizacją niemożliwe miało

${ }^{28}$ Art. $119 \mathrm{~g} \S 1$ pkt 4 O.p. 
być bowiem określanie takich czynności odpowiednich, które wskazywałyby na obowiązek płatnika do obliczenia, pobrania i odprowadzenia podatku.

Dopuszczenie stosowania klauzuli do płatnika wydaje się pozostawać sprzeczne z założeniem, iż klauzula znajduje zastosowanie wyłącznie w ramach postępowań przewidzianych Ordynacją podatkowa. Przy przyjęciu bowiem, że klauzuli nie stosuje się z mocy prawa, w momencie dokonania czynności płatnik nie ma żadnych podstaw, by uwzględnić jej treść przy obliczaniu i wymiarze podatku. Nie ma więc on prawa obliczyć, pobrać i odprowadzić podatku w innej wysokości, niż wynikałoby to z przepisów materialnoprawnych innych niż klauzula przeciwko unikaniu opodatkowania.

Również późniejsze wydanie decyzji na podstawie art. 119a O.p. nie może skutkować odpowiedzialnością płatnika. Zgodnie z art. 30 § 1 O.p. płatnik odpowiada bowiem za podatek niepobrany lub podatek pobrany, a niewpłacony wyłącznie wtedy, gdy nie wykonał on swoich obowiązków płatnika. Jeżeli przyjąć, że obowiązek podatkowy powstaje dopiero w momencie wydania decyzji na podstawie art. 119a O.p., w momencie przekazywania płatności na rzecz podatnika obowiązek pobrania podatku nie istnieje, więc płatnik nie jest zobowiązany do jego realizacji. To zaś oznacza, iż w modelu, w którym klauzulę może zastosować tylko organ, trudno jest przyjąć odpowiedzialność płatnika na podstawie tej normy. Jej zastosowanie musiałoby bowiem skutkować nałożeniem na płatnika obowiązku ze skutkiem wstecznym. Byłoby to rażąco niesprawiedliwe, biorąc pod uwagę, że płatnik na moment dokonania czynności nie dysponowałby alternatywną drogą działania, w szczególności nie miałby żadnej podstawy prawnej do pobrania podatku od podatnika ${ }^{29}$.

\section{PODSUMOWANIE}

Podsumowując przeprowadzone rozważania, wydaje się, że w obecnie obowiązującym stanie prawnym w dalszym ciagu przeważają argumenty, iż klauzula przeciwko unikaniu opodatkowania, w sytuacjach gdy spełniona jest jej hipoteza, znajduje zastosowanie z mocy prawa. Decydujące znaczenie należy przypisać tu literalnemu brzmieniu ustawy, które, w ocenie autorów, wskazuje na automatyzm stosowania tej normy. Ponadto odwołanie w treści przepisów do możliwości wydania na podstawie art. 119a O.p. „decyzji określającej” wskazuje, iż istotą stosowania klauzuli jest doprowadzenie pierwotnie nieprawidłowego rozliczenia podatnika do prawidłowego stanu, a nie konstytutywne doszacowanie podatku ex post.

Powyższe oznacza, iż podatnik, ustalając wymiar podatku, ma prawo, ale i obowiązek ustalić, czy zrealizował działania kwalifikujące się jako unikanie opodatkowania, a jeżeli tak, to rozpoznać ich skutki na podstawie art. 119a

${ }_{29}$ Niesprawiedliwość ta byłaby jeszcze bardziej rażąca, gdyby na płatnika został dodatkowo nałożony obowiązek zapłaty dodatkowego zobowiązania podatkowego. 
§ 2-6 O.p. Jeżeli tak uczyni, nie będzie mu groziło wymierzenie przez organ podatkowy dodatkowego zobowiązania podatkowego.

Najmocniejszym przeciwnym argumentem wskazującym, że klauzulę powinien stosować sam podatnik, jest uzasadnienie ustawy zmieniającej. Dokument ten jednoznacznie oddaje intencję projektodawców ustawy zmieniającej, aby klauzulę stosowało się wyłącznie w toku postępowań przed Szefem KAS. Projektodawcy, bazując na błędnym, w naszym przekonaniu, założeniu, iż ta zasada obowiazywała od momentu wprowadzenia klauzuli, nie wprowadzili jednak do O.p. przepisów, które odzwierciedlałyby to założenie. W rezultacie z przepisów Ordynacji podatkowej nadal wynika, że do stosowania klauzuli zobowiązany jest sam podatnik.

Omawiana w niniejszym artykule kwestia, ze względu na potencjalną sporność, wymaga w ocenie autorów pilnego, jednoznacznego doprecyzowania. Sytuacja, w której istnieja wątpliwości, czy podatnik, ustalając wymiar podatku, jest zobowiązany do uwzględnienia klauzuli, jest trudna do zaakceptowania. Zwłaszcza gdy za ewentualne umyślne błędy w deklaracji grozi mu odpowiedzialność karna skarbowa.

De lege ferenda w naszej ocenie klauzula powinna stanowić typowy przepis materialnoprawny znajdujacy zastosowanie z mocy prawa. Równocześnie dla ochrony interesów Skarbu Państwa wskazane byłoby wprowadzenie obowiązku raportowania Szefowi KAS przypadków, gdy podatnik samodzielnie zastosował normę antyabuzywna, ze szczegółowym wskazaniem towarzyszących temu okoliczności.

Bartosiewicz, A. (2017). „Agresywna optymalizacja podatkowa” a odpowiedzialność karna skarbowa. Przegląd Podatkowy 9: 29-35.

Działocha, K., Łukaszczuk, A. (2016). Komentarz do art. 84 Konstytucji, [w:] L. Garlicki, M. Zubik (red.), Konstytucja Rzeczypospolitej Polskiej. Komentarz. Warszawa: 965-988.

Dzwonkowski, H., Dzwonkowski, M. (2020). Komentarz do art. 5 O.p., [w:] H. Dzwonkowski (red.), Ordynacja podatkowa. Komentarz. Warszawa. Legalis/el.

Filipczyk, H. (2016). Stosowanie klauzuli ogólnej przeciwko unikaniu opodatkowania - zagadnienia wybrane. Monitor Podatkowy 7: 12-17.

Gomułowicz, A. (2019). Klauzula przeciwko unikaniu opodatkowania, czyli - Ave Caesar, morituri te salutant. Przegląd Podatkowy 10: 14-20.

Guzek, M., Stefaniak, M. (2018). Klauzula przeciwko unikaniu opodatkowania. Komentarz praktyczny. Warszawa. Legalis/el.

Jankowski, J. (2020). Przesłanki materialnoprawne stosowania GAAR - wybrane zagadnienia. Monitor Podatkowy 1: 22-26.

Kondej, M. (2018a). Klauzula przeciwko unikaniu opodatkowania. Komentarz do przepisów materialnoprawnych. Poznań.

Kondej, M. (2019). Klauzula przeciwko unikaniu opodatkowania jako norma znajdująca do 31 grudnia 2018 r. zastosowanie ex lege. Kwartalnik Prawo Społeczeństwo-Ekonomia 1: 5-14.

Kujawski, G. (2017). Klauzula generalna unikania opodatkowania Komentarz do zmian w ordynacji podatkowej. Warszawa. Lex/el.

Kuźniacki, B. (2020). Dekodowanie hipotezy GAAR: przesłanki intencji i sprzeczności oraz relacje między nimi, cz. 1. Przegląd Podatkowy 6: 19-41.

Ladziński, A. (2019). Zmiany w ogólnej klauzuli przeciwko unikaniu opodatkowania - powrót do przeszłości. Przegląd Podatkowy 1: 22-28.

Liszewski, G. (2021). Komentarz do art. 119zfa Ordynacji podatkowej, [w:] L. Etel (red.). Ordynacja podatkowa. Komentarz aktualizowany. Lex/el. 
Łukawska-Białogłowska, D. (2020). Komentarz do art. 119zfa O.p., [w:] H. Dzwonkowski (red.), Ordynacja podatkowa. Komentarz. Warszawa.

Niezgódka-Medek, M. (2019). Komentarz do art. 5 O.p., [w:] S. Babiarz, B. Dauter, R. Hauser, A. Kabat, J. Rudowski, M. Niezgódka-Medek, Ordynacja podatkowa. Komentarz. Warszawa. Lex/el.

Olesiak, J., Pajor, Ł. (2020). Komentarz do art. 199a O.p., [w:] H. Dzwonkowski (red.), Ordynacja podatkowa. Komentarz. Warszawa. Legalis/el.

Olesińska, A. (2013). Klauzula ogólna przeciwko unikaniu opodatkowania. Toruń.

Porada, Ł. (2021). Komentarz do art. 119zfa O.p., [w:] A. Mariański (red.), Ordynacja podatkowa. Komentarz. Warszawa: 599-600.

\section{THE POLISH GENERAL ANTI-AVOIDANCE RULE: \\ A REGULATION TO BE APPLIED BY A TAXPAYER \\ OR ONLY BY THE TAX AUTHORITIES DURING TAX PROCEEDINGS?}

\section{Sum mary}

The article discusses whether the Polish general anti-avoidance rule (GAAR), especially in the light of the amendments binding as of 1 January 2019, is supposed to be applied by a taxpayer during the calculation of due tax, or whether only the tax authorities are authorized to apply the GAAR during tax proceedings. The authors claim that the GAAR is applicable ex lege. They criticize the justification for amendments to the tax ordinance introduced as of 1 January 2019, which states otherwise, pointing out that the interpretation adopted in this justification leads to contradictions in the law.

Keywords: anti-avoidance rule; GAAR; constitutive decision; declaratory decision; tax proceedings; discretion; tax ordinance 
